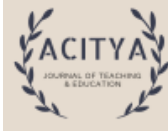

Acitya: Journal of Teaching \& Education, Vol. 3 No. 22021

Acitya: Journal of Teaching \& Education

Website: http://journals.umkt.ac.id/index.php/acitya

Research Papers, Review Papers, and Research Report

Kampus 1 UMKT JI. Ir. H. Juanda No 15, Samarinda, Indonesia 75123

\title{
SOCIAL STRATIFICATION ON THIS EARTH OF MANKIND BY PRAMOEDYA ANANTA TOER'S NOVEL
}

Hesti Miranda

National Dong Hwa University

Email: hestimiranda8@gmail.com

\begin{abstract}
This Earth of Mankind by Pramoedya Ananta Toer is a historical novel about Dutch colonialism in Indonesia. This paper was aimed to find and describe the social stratification in the past that is written in the This Earth Mankind novel. This paper was carried out with one research question: How is social stratification of This Earth Mankind by Pramoedya Ananta Toer's Novel? This paper was qualitative research, specifically in document analysis. The main source of this paper was This Earth of Mankind, the 9th edition publishes by Hasta Mitra in 2002. This paper found that there were three social classes of society in the Dutch era, the Dutch group with privilege, enjoyed the lavish life, and live comfortably. The Native group with privilege, who was born from regent or governor, they can attend education where Dutch and Indo attended to such as E.L.S and H.B.S and the last, native group without privilege, they had low status in the society.
\end{abstract}

\section{Keywords: This Earth of Mankind, Social Stratification, Dutch Education Program}

\section{INTRODUCTION}

\subsection{Introduction}

In the past, colonial has widely known as act to controlling the certain country. Colonialist controls economic, government, even society. Colonialist might bring negative and positive effect. In Indonesia, there many countries that had been colonize Indonesia, but the longest one is Dutch. Dutch colonialism influences every aspect in Indonesia till now. The culture, language, system in government and education are effect from Dutch colonialism. Nawawi (1971) stated that in several was, colonialism have contributed to the growth of nationalism of Indonesia. Colonial government creates the chance for modern education that in the future produce nationalist leader of Indonesia. It also produces the nationalist movement in the future. From Nawawi's statement we can know that one of the contributions from Dutch colonialism is education. 
Dutch education indeed helped Indonesian at that time. It reduced illiterate Indonesian even though just for certain people. Finkelstein (1951) stated that Indonesian citizens are provided fine European-style education under Dutch colonialism. Their educations are best equivalent in Europe for Dutch high school for instance. President Sukarno and Sutan Sjahrir are Indonesian nationalist leaders who graduate from Dutch education. In Sjahrir's book out of Exile, he wrote that Dutch internment camps showed western knowledge. But this is only for privileged education only for certain people such as Indonesian royal and aristocratic families. It means that the education provided by the Dutch government cannot be provided equally for everyone.

The equality of education in the Dutch government is already known widely and it was written in the history of Indonesia. It was saved inform of achieved. These achieve are document, book, picture and et cetera. All of the histories are deliver to the generation thought to history subjects in the school. Furthermore, for some people history also inspired them to make a story that related to things in the past. One of the greatest novelists is Pramoedya Ananta Toer. He was born on 6 February 1926, blora Easy Java. He was work in a Japanese news agency as a stenographer. When Indonesia announces the proclamation he joined and become the new Indonesian nationalist army. He was imprisoned by Dutch till the end of the Revolution in December 1949. While in prison, we wrote many short stories, a novelette, and novels. All of this work is smuggle out and later it was published. All of his work is published in Jakarta but also it was banned (Haridas, 1978). But the most famous novel that he published was the Buru Quartet. Schultz \& Felter (2002) stated that he wrote his Buru quartet where it aimed to understand himself and his difficult life in Indonesia. He had been arrest three times in different regimes. His works such as this earth of mankind in 1975; 1990, child of all nations 1975;1990, house of glass 1988;1992 have been translated into English and it gains popularity in the west. All of Buru quartet also gain popularity since this earth of mankind is filmed. In this film, Minke is the protagonist character that attracts the audience because of his character.

Minke is a character that Pramoedya Ananta Toer creates based on a true story and some imagination. This character has a strong impression on the audience. Schultz \& Felter, (2002) stated that Minke is a young Javanese narrator that represents himself as a student of a European school. He was captivated by European knowledge, everything relates to Western such as the new telegraph, zincography, European manner. He studies that civilizing missions will give advantages to the Indies (Indonesia). The strong character also showed in some actors in the movie. Besides, the background of the film is thick with Indonesian culture in 
the past that mix Indonesian culture and Dutch culture which show clearly in the movie. You can see the social stratification of indigenous people and Dutch people that live together in a society but with different condition.

Social stratification is intrigued topic that is talked especially in this novel. Social stratification in the past has a strong line. Hence, the researcher conducted this research entitle Social stratification on This Earth of Mankind by Pramoedya Ananta Toer's Novel. The research topic of this study is How is social stratification depicted in This Earth Mankind by Pramoedya Ananta Toer's Novel?. This study aims to find the social stratification in the past that is reflected in the movie This Earth Mankind.

\subsection{Research questions}

How is social stratification depicted in This Earth Mankind by Pramoedya Ananta Toer's Novel?

\subsection{Significance of the study}

This study is expected to be a reference in the future. Giving an understanding about social stratification that existed in the literature that might rare to be found especially in the novel which has a historical setting. Hopefully, this study might give another insight about sociology in education that might be found in the literary novel. This study also can be used in the classroom as the supplementary material in the teaching and learning process. It can describe the social stratification that exists in the novel This Earth of Mankind novel.

\section{METHOD}

\subsection{Research Design}

This study uses qualitative research specifically is document analysis. Based on Ary et. al. (2010:457) stated that document analysis is a research method that aims to identify certain features of material through written or visual. Materials could in form of a textbook, newspaper, web pages, speech, advertisements et cetera. There are many purposes of content analysis or document analysis as follows.
a. Identifying bias, prejudice, or propaganda in the materials
b. Analyzing kinds of errors in the writings
c. Describing prevailing practices
d. Discovering the degree of difficulty in the material such as textbook or publication
e. Discovering the vital of, or interest in certain topic 
Based on the purposes above, those are commons aims for research to use document analysis or content analysis as research methods. According to Ary et. al. ( 2010, 458) explained that some steps that might include before conducting content analysis:

1. Specifying the phenomenon to be investigated

2. Choosing the media from what observations are to be made

3. Formulating exhaustive and mutually exclusive coding categories so the verbal or symbolic content can be counted

4. Determining the sampling that will be used to get a representative sample of the documents

5. Training the coders so that coders can consistently apply the coding scheme that has been developed and will take parts as reliability of the document analysis

6. Analyzing the data

\subsection{Research Object}

This study uses primary sources Novel by Pramoedya Ananta Toer, $9^{\text {th }}$ edition that has been released by Hasta Mitra in October 2002. The total page of this novel is 405, and it has 20 chapters without titles. This Earth of Mankind is the first quartet of four novels written by Pramoedya Ananta Toer. In addition, secondary sources also needed such online information about the writer and previous researcher such as Sofi \& Basiri (2020) and Fachrullah (2015) who has been conducted similar research about This Earth of Mankind. The primary instrument of this study is the researcher herself.

\subsection{Instruments}

In this research researcher used herself as an instrument to gain the data and create an interpretation and draw conclusion.

\subsection{Data analysis}

Data collection for this study provided steps to analyze the This Earth of Mankind. The steps are 1) determining the object of this research, 2) deciding the data source for primary and secondary data, 3) determining the data collection, and 4) choosing the technique to collect the data. Besides steps, data are analyzed such as 1) researcher read literature review related to social stratification, 2) Researcher read novel This Earth of Mankind, 3) Researcher tried to find the category of social stratification based on Collins (1971) theory in the novel such as status group, and struggle for advantages, 4) researcher select the scene in the novel based on social stratification based on Weber theory, and last 5) researcher gave interpretation and conclusion. 


\section{FINDINGS AND DISCUSSION}

\subsection{Findings}

\subsubsection{Dutch Group with privilege}

Pramodya Ananta Toer writes a novel with Minke as protagonist and his relationship with Herman Mellema's family. Herman Mellema is a pure Dutch who has an occupation as a businessman, he have higher status in society. It describes in the novel:

“dan setiap penduduk Surabaya dan Wonokromo, kiraku, tahu belaka: itulah rumah hartawan besar Tuan MEllema-Herman MEllema. Orang menganggap rumahnya sebuah istana pribadi, sekalipun hanya dari kayu jati. Dari kejauhan sudah Nampak atap sirapnya dari kayu kelabu. Pintu dan jendela terbuka lebar. Tidak seperti rumahpelesir Ah Tjong. Berandanya tidak ada. Sebagai gantinya sebuah konsol cukup luas dan lebar melindungi anaktangga kayu yanglebar pula. Lebih lebar daripada pintu depan" ((Toer, 2002, 12).

Translation:

"and every resident of Surabaya and Wonokromo, I think, knows well: that is the house of the great billionaire Mr. Herman Mellema. People consider his house as private palace, even if only made of teak wood. From a distance, the shingle roof is made of gray wood. The doors and windows were wide open. Not like Ah Tjong's vacation house. There is no veranda. Instead, a console is wide and wide enough to protect the wide wooden steps. Wider than the front door"

From this description, Herman Mellema a Dutch who has lavish. Even his house was only made from wood, but in the colonial era, he is a rich man based on the description even though his house is made from teak wood but it looks like a private palace. It is not only that, but he also has a big farm that produces many things but the most famous is milk. Herman Mellema is not the only person who enjoys the lavish life, most Dutch people live comfortably. It is even applied to Dutch who have fanatic radicals. Fanatic radical people are who think that Hindia (Indonesia) is the same as Nederland. Those people will not get punishment, they just are asked to leave Hindia. But for native people who support them, they will get severe punishment as describe in the novel

“.........sekali orang liberal dikutuk pemerintah-tak peduli apa salahnya, kalo dia Totok, dia paling-paling diperintakan meninggalkan HIndia. Kalau dia Indo, akibatnya lebih pahit, dia akan kehilangan pekerjaa. Kalau pribumi, kiraku, dia kan kehialngan kebebasannya, disekap tanpa melalui pengadilan-karena memang taka da hokum khusus tentang itu. Nah, Tuan, hati-hatilah, jangan sampai tuan hanya kena getahnya..."((Toer, 2002).

“......once a liberal is condemned by the government-no matter what the fault, if he is pure blood (Dutch), he is at most ordered to leave Hindia. If he is Indo, the result will be bitterer, he will lose his job. If it's a native, I think he's lost his freedom, being held without going through a trial-because there's no special law about that. Well, sir, be careful, don't let the master just get hit by the effect..."

From it, the author gives the effect of what will happen to people who support radical people based on social status. If she or he as Totok or pure Dutch blood, he or she will be asked to leave from Indonesia, if Indo, people who have mixed blood between Dutch and 
Native, they will lose the job, and for native, will not get her/his freedom, prison without any court directly.

\subsubsection{Native group with privilege}

The native character in this novel is the main character, Minke. Minke is an H.B.S. student, however, the novel describes that he did not have a surname. In the past, the citizen who did not have a surname, it means that they were native. Even like indo (it is a term to call mix blood Dutch and Indonesia) who did not get their surname because the father did not recognize him or her in the court. The court later will create a legal paper that this Indo is already accepted by a Dutch person. If they did not have a legal paper, they are not different from native people who have low status. The way people will know the person that they meet is a person has higher or low status based on the surname that that person has. The author makes it clearer when Minke meets Analies and ask his name:

“mengapa kau sembunyikan nama-keluargamu?” tanyanya.

“tidak ada kusembunyikan,” jawabku, dan mulai gelisah lagi.

“Apa perlu benar kusebutkan?”. Aku lirik Robert Suurhorf. Ia tidak tertikam oleh lirikanku. Ia sedang asik tenggelam dalam sepakbolanya dengan Robert Mellema. Sebelum aku tarik lirikanku mendadakan ialah yang justru melepaskan lirikannya.

“tentu," sambut Annelies. "nanti disangka kau tak diaku oleh ayahmu".

"Aku tak punya. Betul-betul tak punya," jawabku nekad.

“oh!” serunya pelan. "mafkan aku.”ia terdiam sejenak. "Tak punyapun baik,” katanya kemudian.

“Aku bukan indo," tambahku engan nada membela diri.

“oh?” sekali lagi iya berseru. "bukan?"

Rasanya ada gendang bermain dalam jantungku. Dia sudah tahu sekarang: aku pribumi. Pengusiran setiap saat bisa terjadi. (Toer, 2002,15).

Translation:

"Why did you hide your surname?" he asked.

"I have nothing to hide," I replied, and began to get restless again.

"Do I really need to mention?". I stared Robert Suurhorf. He wasn't stabbed by my stare. He is currently immersed in his football with Robert Mellema. Before I pulled out my sudden glance was what actually released his glance.

"Sure," said Annelies. "You'll think you're not recognized by your father."

"I do not have. I really don't have one, "I replied desperately.

"Oh!" he shout softly. "I'm sorry." He paused for a moment. "None of them are good," he said later.

"I'm not Indo," I added defensively.

"Oh?" once again yes exclaimed. "not?"

It felt like a drum was playing in my heart. He knows now: I'm a native. Expulsion at any time can occur.

From the detailed story, Minke though that because he will be dragged out from Mellema's house because Annelies knew that he was not Indo, but a Native person. From this, we can know that Indo does not like Native people. Minke who native person, there is a chance for him to be dragged out from that house, because of his level in society. Minke also introduces himself as an H.B.S. student. H.B.S. it is not a mere school that can be attended by 
native people. Whoever wants to attend H.B.S., she or he must be a descendant of regent or governor. In the novel, Annelies mother who usually is called Nyai Ontosoroh also asks Minke about his father. She asked if he (Minke) is an H.B.S student, he must be a son of regent or governor. From which region your father lead? Minke said that he is not. Then, it is revealed in the novel that Minke is an H.B.S. student. From the explanation from the author, people who can attend this school only pure Dutch, Indo (mix blood Dutch and native), and native (children from regent or government). In the past, the school intended for those people only. The novel also revealed that most Indo or native who has higher rank will attend E.L.S then they will continue their school to H.B.S.

When Minke graduated from E.L.S and continues his education into H.B.S. he knew that his name as his teacher called him, Minke derived from the word monkey. It is clear that the status of native people even though he has attended European school but still Dutch people mock him as well as in page 43 that Mellema saw Minke in his house :

"Kowe kira, kalo sudah pake pakean Eropa, bersma orang Eropa, bisa sedikit Belanda lantas jadi Eropa? Tetap Monyet!"

Translation:

"You think, if you wear European clothes, together with Europeans, you can be a little Dutch and then become European? Still Monkey!"

It can be concluded that Herman Mellema thinks that even though Minke can speak Dutch, his outfit also like European, and he lives surrounding Dutch people it does not mean he is Dutch also, but his status still a monkey. In the story, Minke has Privilegatum Forum that only belongs to an aristocrat. In the novel Toer also defines Privilegiatum forum: is an equal forum with Europeans in front of the court for native nobility down on the title Raden Mas or equivalent and children to grandchildren of regents. (on page 125). Meanwhile, the minke position around the regent is still low. So that whenever he encounters regent or governor who is native people also, Minke has to respect them with Java culture as described in the novel:

“ Jadi aku akan dihadapkan pada Bupati B. God! Urusan apa pula? Dan aku ini, siswa H.B.S., haruskah merangkak dihadapannya dan mengangkat sempah pad setiap titik kalimatku sendiri untuk oang yang sama sekali tidak ku kenal? Dalam berjalan ke pendopo yang sudha diterngi dengan empat buah lampu itu aku merasa seperti hendak menangis. Apa guna belajar ilmu pengetahuan Eropa, bergaul dengan orang-orang Eropa, kala akhirnya toh harus merangkak, beringssut sepeti keong dan menembah raja kecil yang barangkali butahuruf pula? God, God! Menghadap seorang bupati sama dengan bersiap menampung penghinaan tanpa boleh membela diri. Tak pernah aku memaksa orang lain berbuat semacam itu dihadapapanku. Mengapa harus aku lakukan untuk orang lain? Samabar geledek! (Toer, 2002: 130-131).

\footnotetext{
"So I will be met by Regent B. God! What's the matter? And I, an H.B.S. student, have to crawl in front of him and swear at every point of my own sentence to someone I don't know at all? As I walked to the pavilion, which was already lit with four lamps, I felt like I was about to cry. What's the use of studying European science, associating with Europeans, when in the end you have to crawl, shuffle like a snail and slay a little king who may well be illiterate? God, God! Facing a regent is the same as being prepared to accept humiliation without being able to defend oneself. I've never forced anyone to do that in front of me. Why should I do it for someone else? Thunderstorm!
} 
From this story, it was Java culture when you had to meet a person who has higher status as a regent, you had to walk to them crawling. And every sentence in your answer toward him was supposed to like worship him. In minke feeling, even though he is an H.B.S. student who has higher status and as an educated person, he also must crawl to meet regent who might be illiterate. Someone who appointed by the Dutch government as a regent of a certain region, but the person he meets actually is his own father. So that is why he called minke back to B. In contrast, his father is graduated from common school and it is different from Minke's school. Minke can speak Dutch, knows Dutch people, and have a wide network. It is contrasted with his father who only graduated from low society and he does not have any network with Dutch, people around him also surprises he is appointed as regent and the more important thing is he cannot speak Dutch. Hence, he needs minke to help him in the ceremony.

\subsubsection{Native group without privilege}

In the novel, Minke's life is much better than Nyai Ontosoroh who was sold by her parent to get money from Mr. Mellema. In the story, Nyai Ontosoroh was a daughter that is sold by her parents to Mr. Mellema as a concubine. In the story, she managed all of the company like a privileged woman who got higher education, she could write, spoke Dutch and she could manage a company. Minke also curious, then Pramoedya Ananta Toer explain in the story where Annelies and Nyari Ontorosoh slept together and revealed her past:

\footnotetext{
“Ma, pandai Papa dulu, Ma?"

"Bukan saja pandai, juga baikhati. Dia yang mengajari aku segala tentang pertania, perusahaan, pemeliharaan hewan, pekerjaan kantor. Mula - mulai diajari aku bahasa Melayu, kemudian membaca dan menulis, setelah itu juga bahasa Belanda. Papamu bukan hanya mengajar, dengan sabar juga menguji semua yang telah diajarkannya. Ia haruskan aku berbahasa Belanda dengannya. Kemudian diajarinya aku berurusan dengan bank, ahli-ahli hokum, aturan dagang, semua yang sekarang mulai kuajarkan juga padamu” (Toer, 2002:78)
}

Translation:

"Ma, Papa was smart, Ma?"

"Not only smart, but he also kind. He's the one who taught me everything about agriculture, companies, animal husbandry, and office work. At first, I was taught Malay, then reading and writing, then Dutch too. Your papa not only taught, patiently also tested everything he had taught. He had me speak Dutch with him. Then he taught me how to deal with banks, legal experts, trade rules, all of which I am now beginning to teach you too".

Nyai Ontosoroh's life was not in her hand, but in her parents who sold them. She was lucky that being sold to Mr. Mellema because he has the intention to took Nyai Ontosoroh as such wife who bore his children and managed the house. Another woman is not lucky enough like her. They might be sold to Dutch people who used only for sleep. But still, even though she knows everything, but everything is not her right, including her children. She told Annelies in the story: 
"Mamamu, hanya perempuan Pribumi, akan tidak mempunyai sesuatu hak atas semua, juga tidak dapat berbuat sesuatu untuk anakku sendiri, kau, Ann. Percma saja akan jadinya kita berdua membnting tulang tanpa hari libur ini. Percuma aku telah lahirrkan kau, karena Hukum tidak mengakui keibuanku, hanya karena aku Pribumi dan tidak dikawin secara syah. Kau mengerti?" (Toer, 2002:79).

Translation:

"Your mother, only an Indigenous woman, will have nothing to rigth, nor can you do something for my own child, you, Ann. It's a shame that we'd both be working hard without this day off. It's useless that I gave birth to you, because the Law does not recognize my motherhood, just because I am Native and not legally married. You understand?"

She said that she has nothing. In the story, she lived lavishly because she worked every day without a day off, but she realized that it will be taken from her when Mr. Mellema back to Netherland. She also mentioned that even her son and daughter were not belonging to her. Furthermore, people who are able how to read and write in the past will get a good position. In the story, Nyai Ontosoroh's father was a respected person in her village since her father was able to read and write. He even got a position in the office as a writer. However, his right was still limited. He could not get his little brother, and cousin to work in the factory. If he wanted all of his family to work in the factory, he must be a foreman who has many rights in the factory.

\footnotetext{
" kata orang, ayahku seorang yang rajin. Ia dihormati karena satu-satunya yang dapat baca-tulis di desa, baca tulis yang dipergunakan dikantor. Tapi ia tidak puas hanya jadi jurutulis. Ia impikan jabatan yang lebih tinggi, sekalipun jabatannya sudah cukup tinggi dan terhormat. Ia tak perlu mencangkul atau meluku atau berkulli, bertanam atau perpanen tebu(Toer, 2002:81).
}

Translation:

"People say, my father is a diligent person. He is respected because the only one who can read and write in the village, read and write is used in the office. But he was not content to just be a clerk. He dreams of a higher position, even though his position is quite high and honorable. There is no need for hoeing or cultivating or cultivating, planting or harvesting sugar cane .

Her father worked in the factory for more than ten years, his position and rank did not increase. Only salary and yearly percent always increase. His dream was to be a cashier in the sugar factory Tulanga, Sidoarjo. It never happens, because he was a native. Native people life also life miserable, they do not know everything that besides work for surviving in their life.

"ia melangkah padaku, membuka bibirku dengan jari-jarinya. Dengan isarat ia perintahkan mulai sejak itu menggosok gigi. Maka ia tuntun aku pergi ke belakang, ke kamar mandi. Itulah untuk pertama kali aku melihat sikatgigi dan bagaimana menggunakanya. Ia tunggui aku sampai selesai, dan gusiku rasnaya sakit semua” (Toer, 2002:89)

Translation:

"He stepped up to me, opened my lips with his fingers. With a gesture he ordered from then on to brush his teeth. So he led me to the back, to the bathroom. That was the first time I saw a toothbrush and how to use it. He was waited for me to finish, and my gums hurt all over".

From nyai Ontosoroh's perspective, the way she lives is like know nothing. When she is taken to Mr. Mellema's house, everything is unfamiliar for her. In that house, for the first time, she knows about toothbrushes when Herman Mellema brushed her tooth because she never sees a toothbrush and Mr. Mellema teaches her how to use it. Not only the toothbrush, 
but she also does not know the towel. The first time Mr. Mellema use a towel to dry her hair. after that, she knows that thing is called a towel.

"'ia gendong aku masuk ke rumah, ke kamar. Didudukannya aku didepan sebuah cermin. Ia gosok rambutku dengan selembar kain tebal, yang kelak aku ketahui bernama anduk, sampai kering, kemudian ia minyaki- begitu wangi baunya. Aku tak tahu minyak apa. Dialalh juga nag menyisi aku seakan aku tak bisa bersisir sendiri. Ia mencoba mengkondai rambuku tapi tak bisa dna membiarkan aku menyelesaikan"(Toer, 2002:89)

Translation:

"'He carried me into the house, into the room. I sat in front of a mirror. He rubbed my hair with a thick piece of cloth, which I later learned to be called towel, until it was dry, then he oiled it - it smelled so good. I don't know what oil. He also stayed by my side as if I couldn't brush myself. He tried to condition my hair but couldn't and let me finish".

From this, the author is trying to show how the life of native people who do not know what is toothbrush and towel. Only Dutch people used it regularly. Mr. Mellema also teaches Nyai Ontosoroh who to dress and choose a good color. He said that she (Nyai Ontosoroh) must be always looking beautiful. A wrinkled face and messy clothes are also a reflection of a disheveled business that cannot be trusted.

The current system and back then are similar. We have Regent and head of the village. The novel describes that in the ceremony of Minke's father that when the ceremony finished. There were many congratulatory regents; however, it was a greeting not long. Minke described that congratulatory did not take much time. The head of villages were not allowed to shake hands as greeting the regent. So, my father saved his hand from the goods of one thousand two hundred positions of the village officials. They just sat on the mat in the yard there. The entire rule from Dutch was absolute. Native cannot fight back European court, because they did not have right.

In the colonial era, the law is created by Dutch, Dutch run the law. If the native people are trying to fight the Dutch government, the result is clear, they will fail. Native people cannot fight back European court. Even though in the story, Nyai Ontosoroh and Minke fought to get the right of Annelies, and they paid much money to hire famous advocates but still their efforts in vain. The way was that Nyai Ontosoroh suggests to Minke through writing. It is because the newspaper was a vital tool in the Dutch era, news has a strong influence to provoke society whether is a right story or fake story. In the court also there was a big line that draws from the prosecutor that teasing Nyai Ontosoroh and Minke. The court function as undressing their life in Mellema's house, the question that was given by the prosecutor did not relate with Herman Mellema. The trial went awry. The entire court situation showed European court has a high position in society. Indo, a term for a child who has mixed blood between native and Dutch has a right under European law if the father recognizes her. But the mother, who was birth to her will not be recognized because she was 
not Dutch so that European law will not protect her. Native did not have any right toward European court in Hindia as describe:

"memprotes? Lebih dari itu-menyangka. Aku tau mereka orang eropa, dingin, keras seperti tembok. Kata-katanya mahal. Dia anakku, aku bilang. Hanya aku yang berhak atas dirinya. Aku yang melahirkan,membesarkan. Hakim itu bilang: dalam surat-surat disebutkan Annelies Mellema anak akuan Tuan Herman Mellema. Siapa ibunya, siapa yang melahirkan? Tanyaku. Dia dalam surat-sura itu disebutkan perempuan Sanikem alias Nyai Ontosorh, tapi.... Akulah Sanikem. Baik, katanya, tapi Sanikem bukan Mevrouw Mellema. Aku bisa ajukan saksi, kataku, akulah yang telah lahirkan dia. Dia bilang: Annelies Mellema berada dibawah Hukum Eropa, Nyai tidak. Nyai hanya Pribumi. Sekiranya dulu Juffrouw Annelies Mellema tidak diakui Tuan Mellema, dia Pribumi dan pengadilan Putih tidak punya sesuau urusan. Nah, Minke, betapa menyakitkan!......(Toer, 2002:368).

Translation:

"protest? More than that-thought. I know they are European, cold, hard as a wall. Words are expensive. He's my daughter, I said. Only I have the right to him. I give birth, raise. The judge said: in the letters it was stated that Annelies Mellema was the son of Mr. Herman Mellema. Who is the mother, who gave birth? I asked. She is mentioned in the letters as a woman Sanikem alias Nyai Ontosorh, but... I am Sanikem. Fine, he said, but Sanikem was not Mevrouw Mellema. I can present a witness, I said, I was the one who gave birth to him. He said: Annelies Mellema is under European law, Nyai is not. Nyai only Native. If in the past Juffrouw Annelies Mellema had not been recognized by Mr. Mellema, he was Native and the White court had nothing to do with it. Now, Minke, how painful!......"

\subsection{Discussion}

\subsubsection{Dutch with Privilege}

From the result, Dutch people have lavish life, Mr. Herman Mellema for instance. He has worked as a businessman. But not only him, other Dutch people have privilege also in a society where the position is the highest one. It showed that how much the social stratification in the novel. This result in line with Oyekola \& Oyeyipo(2020) it is vital to know that a job is not only for earning money, it represents the way people live and the degree of prestige that people get. A job has a relation with social status and still shows the class of the society. A job decided the prestige of personnel in society. It means that the standard that people use to determine the class stratification in society is based on what kind of job that someone belongs to. Having money is determined the class position in society. Mr. Mellema also describes life in the private palace because of the big house that he has. It is positive that he has positively privileged properly. This information also provided by Cox (1950) that goods earning is the part of life positively privileged goods. They can take over the economic for example buy the expensive goods, the discount goods, and all chance to stock and they have kind of special advantages to any education.

\subsubsection{Native Group with Privilege}

In the novel, Minke is a protagonist who introduces himself as an H.B.S. student. H.B.S. it is not a mere school that can be attended by native people. Whoever wants to attend H.B.S., she or he must be a descendant of regent or governor. From here we can see that native people were trying to get a higher position in society with makes their children attend 
Dutch school. This is the way of people gain status. This argumentation also supported by Lenski (1984) that power and privilege were trying to take by people who struggles for it, it is the way conflict theorist see human societies. The novel also describes that Herman Mellema thinks that even though Minke is able to speak Dutch, his outfit also like European, and he lives surrounding Dutch people it does not mean he is Dutch also, but his status still a monkey. From this statement, Mr. Herman Mellema has a perspective that he is from supergroup and Minke that he mentions that try to imitate Dutch life, whatever he imitates, but he is still a lower group. Cox (1950) statement also can be related that social subordination and honor title to support of privilege or status group that is being dragged by a caste system. The perception of Mr. Mellema about the honor that he got is the effect of the status group from the society. Besides, Minke has Privilegatum Forum that only belongs to an aristocrat. Privilegiatum forum is an equal forum with Europeans in front of the court for native nobility down on the title such as Raden Mas. This is in line with weber in Collins (1971) stated that an individual is struggling with everybody because the individual identity will represent him or her from a status group. A status group works as their resource in a struggle to get goods (power, wealth, and prestige). These goods can get through the organization. But still, people will struggle because organization is controlled by a different group who has a different status.

\subsubsection{Native group without privilege}

Furthermore, people who are able how to read and to write in the past will get a good position. In the story, Nyai Ontosoroh's father is a respected person in her village since her father is able to read and write. He even gets a position in the office as a writer. Her father works in the factory for more than ten years, his position and rank do not increase. Only salary and yearly percent always increase. His dream is to be a cashier in the sugar factory Tulanga, Sidoarjo. It never happens. These statements are supported by Kemper (1976) stated that capitalist society where labor power is vital. Skilled labor power is needed, they are paid more. The educated people and have skills will be employed. It happened to Nyai Ontosoroh's father that he has the skill to read and write so that Dutch people wanted to hire him to works in the factory.

In the colonial era, the law is created by Dutch, Dutch run the law. If the native people are trying to fight the Dutch government, the result is clear. They will be failed. Native people cannot fight back European court. The story found that Nyai Ontosoroh and Minke tried to get the right of Annelies, and they pay much money to hire famous advocates but still, their effort is meaningless this system is similar to previous research by Cribb (2010) 
stated that the Dutch law system has legal dualism where it took from family law in the colonial administration. This system paid attention to marriage, inheritance, and authority for their children. It means that Dutch has a right to take care of this matter related to Dutch bloodline.

\section{CONCLUSIONS}

\subsection{Conclusion}

The all-status group that shows in the novel The Earth of Mankind has three kinds. They are namely the Dutch group which has privilege, the native group with privilege who are from regent or governor family, and the native group without privilege who are born without any higher income from their family. This novel gives a description of the way Dutch people live lavishly, shows their perspective about native people in Hindia, and they are protected by European law. Meanwhile, native people are described as people who struggle with their life to gain the social status which created by the Dutch government. Those native people were trying to gain the same education as same as Dutch get. Unfortunately for disadvantaged people especially for the case, Nyai Ontosoroh that being sold by her parent is common to happen in the Dutch era that young girl is sold to Dutch people as a concubine. But the struggle for their right in society is hard because the Dutch system is created by the Dutch and it is for Dutch. Furthermore, this Earth of Mankind could be used also in the classroom as literature to students to build experience about the system in the Dutch era and attempt to understand the social stratification and take the lesson from this novel.

\subsection{Suggestions}

This social stratification is prone to conflict theories. Other researchers might need to research about another aspect of social stratification because many experts build of the theories. Analyzing the theories can be done in another perspective from sociology of education.

\section{REFERENCES}

Ary, D., Jacobs, L.C., Sorensen, C., \& Razavieh, A. (2010). Introduction to Research in Education (8th Editio). Wadsworth, Cengage Learning.

Collins, R. (1971). Functional and conflict theories of educational stratification. American Sociological Review, 36(6), 1002-1019. https://www.jstor.org/stable/2093761

Cox, O. C. (1950). Max Weber on social stratification : A critique. American Sociological Review, 15(2), 223-227. https://www.jstor.org/stable/2086786 
Cribb, R. (2010). Legal Pluralism and Criminal Law in the Dutch Colonial Order. Indonesia, Cornel University Press, 90, 47-66. https://ww.jstor.org/stable/20798232

Fachrullah, R. (2015). Equality reflected at This Earth of Mankind novel by Pramoedya Ananta Toer (1975): A Marxist approach. Muhammadiyah University of Surakarta. http://eprints.ums.ac.id/id/eprint/34769

Finkelstein, L. S. (1951). Education in Indonesia. Far Eastern Survey, 20(15), 149-153. https://www.jstor.org/stable/3023860

Haridas, S. A. (1978). Profile: Pramoedya Ananta Toer. Index on Censorship, 7(5), 49-52. https://doi.org/10.1080/03064227808532836

Kemper, T. D. (1976). Marxist and functionalist theories in the study of stratification: Common elements That lead to a test. Social Forces, 54(3), 559-578. https://doi.org/10.1093/sf/54.3.559

Lenski, G. E. (1984). 01PwrPriv Lenski ProbWhoGetsWhatWhy.pdf. In Power and Privilege: Theory of Social Stratification. The University of Notrth Carolina Press.

Nawawi, M. A. (1971). Punitive colonialism: The Dutch and the Indonesian national integration. Journal of Southeast Asian Studies, 2(2), 159-168. https://doi.org/10.1017/S0022463400018580

Oyekola, I.A. \& Oyeyipo, E. J. (2020). Introductory sociology. Obafemi Awolowo Univesity,Press Limitee.

Schultz, D. F., \& Felter, M. (2002). Education, nistory, and nationalism in Pramoedya Toer's “buru quartet." Center for Southeast Studies, 16(2), 143-175.

Sofi, M. J., \& Basiri, N. (2020). Reclaiming identity: Women, social exclusion, and resistance in Bumi Manusia. Sawwa: Jurnal Studi Gender, 15(2), 155-172. https://doi.org/10.21580/sa.v15i2.6646

Toer, P. A. (2002). Bumi manusia (J. Isak (ed.)). Hasta Mitra. 